\title{
Use of a palatal pedicle flap for closure of an oroantral fistula
}

\author{
Fechamento de fístula bucossinusal com retalho palatino pediculado
}

\author{
Cláudio MARCANTONIO' \\ Michelle PALMIERI ${ }^{2}$ \\ Daniel Villela GORGA² \\ Magali de Oliveira PEREIRA² \\ Lélis Gustavo NíCOLI ${ }^{3}$ \\ Waldyr Antônio JORGE 4
}

\begin{abstract}
Sinus lifting has become a routine procedure in modern implant dentistry. Despite its predictability, this type of surgery may eventually lead to serious complications and sequelae. Most of the time, such complications are due to technical failures, such as perforation of the sinus membrane during surgery, which may eventually lead to graft loss due to infection within the sinus, which finds its drainage path into the mouth and leads to an oroantral communication (OAC). Epithelization of such a draining duct characterizes an oroantral fistula (OAF). This report presents the use of a palatal pedicle flap to successfully close an OAF in a patient who had previously undergone a sinus lifting procedure. Several surgical techniques may be used in the closure of an $O A F$, and the choice of a particular technique is subject to the characteristics and location of the communication as well as to the preference of the surgeon. The palatal pedicle flap was successfully chosen in the present case report. The palatal pedicle flap was considered an adequate option for closure of an OAF in a single-stage surgical procedure, with no loss of either keratinized mucosa or buccal sulcus depth in the area of the fistula.
\end{abstract}

Indexing terms: Dental implants. Transplantation. Transplantation homologous.

\section{RESUMO}

A cirurgia de elevação da mucosa do seio maxilar para enxerto ósseo e posterior colocação de implantes osseointegráveis vem se tornando um procedimento de rotina na implantodontia moderna. Embora previsível, em alguns casos, tal procedimento, pode levar a complicações e sequelas consideráveis. Na maioria das vezes, essas complicações são ocasionadas por falhas técnicas, como a perfuração da membrana sinusal no momento transcirúrgico, o que pode acarretar perda do enxerto devido a um processo infeccioso no interior do seio maxilar, cuja via de drenagem acaba provocando a comunicação com a cavidade oral. A fístula bucossinusal é caracterizada pela persistência e epitelização desse pertuito. Neste relato é apresentado um caso de fechamento de fístula bucossinusal com o uso de um retalho palatino pediculado, em um paciente que havia desenvolvido um processo infeccioso, após ter sido submetido à realização de uma cirurgia para a elevação do seio maxilar. A cirurgia para o fechamento das comunicações bucossinusais apresenta técnicas variadas, que podem ser eleitas de acordo com as preferências do operador, além da localização e características da comunicação. Para o presente relato de caso, a técnica do retalho palatino pediculado foi eleita para o tratamento cirúrgico, proporcionando a cura do paciente. A técnica do retalho palatino pediculado mostrou-se uma opção adequada para o fechamento da fístula bucossinusal em um único ato cirúrgico, sem perda de mucosa ceratinizada ou diminuição do sulco vestibular na região da fístula.

Termos de indexação: Implantes dentários. Transplante. Transplante homólogo.

\section{INTRODUCTION}

Over the last decades, with the introduction of the procedure known as "sinus lifting"1-2, implant placement in the posterior portion of the maxilla has become common practice in dentistry. Even after the development of alternative techniques, such as Summers osteotomes ${ }^{3}$ or the use of short implants ${ }^{4}$, bone grafting onto the floor of the pneumatized maxillary sinus still seems to be the most popular and documented technique to address edentulism in the posterior maxilla $a^{5-6}$. Under normal conditions, sinus lifting is a very predictable procedure that shows a rather high success rate. ${ }^{7}$. However, because technical failures can easily lead to graft contamination and oroantral communication, sinus lifting has entered the role of potential etiological factor for oroantral communication ${ }^{8}$,

\footnotetext{
${ }^{1}$ Centro Universitário de Araraquara. Pós-Graduação em Odontologia.

${ }^{2}$ Universidade de São Paulo, Faculdade de Odontologia, Fundação Faculdade de Odontologia. São Paulo, SP, Brasil.

${ }^{3}$ Universidade Estadual Paulista Júlio de Mesquita Filho, Faculdade de Odontologia. Araraquara, SP, Brasil.

${ }^{4}$ Universidade de São Paulo, Faculdade de Odontologia, Departamento de Estomatologia. São Paulo, SP, Brasil.
} 
which, after epithelization, leads to oroantral fistulae. The treatment for these fistulae, regardless of cause or level of progression, encompasses sinus decontamination and surgical closure of the communication, a procedure that should be carried out by an experienced oral surgeon, many times in association with an otolaryngologist ${ }^{9}$. Although not well documented in the literature, it is also important to note that, as any other untreated localized infection process, maxillary sinus infection can progress to a generalized infectious condition and lead to consequences as disastrous as death of the patient.

Several techniques for the closure of oroantral fistulae have been described in the literature. The Rehrmann pedicle flap, the first to be reported and still one of the most widely applied procedures, involves closure of the fistula through occlusal displacement of a trapezoidal buccal flap ${ }^{10}$. Initially described by Egyedi ${ }^{11}$, in 1977, whether by itself or in association with other techniques, occlusal displacement of the buccal fat pad has also been widely used. In this procedure, initial closure is obtained by suturing the buccal fat pad onto the communication, where it facilitates tissue granulation and, ultimately, epithelization ${ }^{12-14}$. No less importantly, an associated procedure that is now frequently used is to suture the released buccal flap to the displaced buccal fat pad, which seems to combine the advantages of both techniques described above ${ }^{15}$.

The first author to report the use of a palatal pedicle flap for closure of an oroantral fistula was Ashley, in 1939. Ever since, several variations of the original technique have been described, such as the anteriorly based palatal flap ${ }^{16}$, the tunnel palatal flap ${ }^{17}$, the divided flap ${ }^{18}$, and the random palatal flap ${ }^{19}$. Except the last, which is primarily supplied by anastomoses spread throughout the palate, all rely directly on the major palatal artery for nutrition. Regardless of the variation used and of personal preferences, it seems consensual in the literature that palatal flaps are richly supplied, present generous thickness, and are very resistant to lacerations. In addition, this flap grants satisfactory mobility, which, albeit limited by its own sturdiness, can be readily achieved, according to experienced authors who have chosen to use this technique ${ }^{10,17,20}$.

Several factors can influence the technical choice of professionals for closure of oroantral fistula, ranging from the specific characteristics of each case to the familiarity or even personal preferences of surgeons for one technique over another ${ }^{17}$. Although certain flexibility is accepted among the most commonly used closing techniques, Borgonovo et al. ${ }^{21}$, in 2012, suggested the use of the buccal flap for closure of oroantral fistulae of moderate size, as long as not too posteriorly located; the palatal flap for fistulae located in the premolar teeth area; and the buccal flap combined with displacement of the buccal fat pad for fistulae located in the third-molar area.

\section{CASE REPORT}

A 49-year-old white male patient underwent a sinus lifting procedure on 03/15/2013. Twenty-one days later, he sought care with signs and symptoms of infection in the operated area, including pain, edema and pus secretion with intraoral drainage. Clinical examination revealed an oroantral communication approximately $1.0 \mathrm{~cm}$ in diameter, with apparent epithelization of its borders and formation of a fistula (figure 1). After a thorough history and clinical examination of the patient, antibiotic therapy was initiated (500 mg amoxicillin combined with $400 \mathrm{mg}$ metronidazole every 8 hours). Forty-eight hours later, a surgical procedure was carried out to remove the infected graft and simultaneously attempt to close the oroantral fistula. After extra- and intraoral disinfection, performed with iodine solution and $0.12 \%$ chlorhexidine digluconate respectively, the mucosa around the fistula was infiltrated with 4\% articaine and epinephrine 1:100.000 and a circular supra-periosteal incision was made with a \#5 blade to remove the epithelial tissue around the border of the fistula and expose the underlying connective tissue (figure 2). Following excision of the epithelial fistula wall, thorough curettage and rinsing of the sinus cavity with saline solution was performed in order to remove as much as possible of the infected and necrotic tissue. This was carried out until sound tissue was macroscopically visible (figure 3). After marking with methylene blue (Tayuyna Laboratories, Nova Odessa São Paulo, Brazil), the flap was divided through an incision carried out on the palatal mucosa, superficially to the periosteum, which was extended posteriorly toward the soft palate through dissection with Metzenbaum-type blunt scissors (figure 4).

After completing incision and dissection, the flap was checked for adequacy of its characteristics, such as dimensions, nutrition and complete passivity. Following this step, the flap was passively positioned and thoroughly sutured over the fistula area with silk sutures (Ethicon ${ }^{\circledR}$ Johnson \& Johnson Medical Limited, New Brunswick, NJ, USA) (figure 5). The donor site was then protected with surgical cement (Coe Laboratories Inc. Chicago, IL, USA), 
held in place by a self-curing acrylic resin plate $\left(\right.$ Jet $^{\circledR}$ Artigos Odontológicos Clássico, São Paulo, São Paulo, Brazil), which had been built over the patient's cast model before the surgery. The acrylic plate was maintained in place for 10 days by fixation with bone screws (Neodent Implantes, Curitiba, Brazil).

On the tenth day after surgery, observation revealed a great degree of granulation tissue at the donor site, as well as encouraging stability at the junction between the apparently healthy pedicle flap and the receptor site.
Twenty days after surgery, healing of the tissues seemed to have progressed, which suggested successful closure of the fistula as well as imminent re-epithelization at the donor site. Antibiotic therapy was suspended at this time.

Clinical evaluation after 30 days showed complete healing and epithelization at the donor site; maintenance of buccal sulcus depth; an abundant band of keratinized mucosa over the grated area; and total closure of the oroantral fistula, which could be verified through a negative Valsalva maneuver (figure 6).

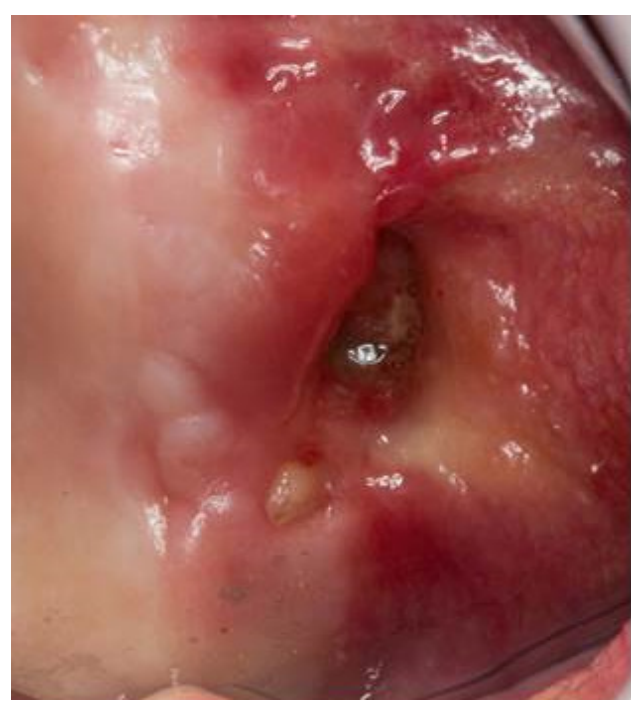

Figure 1. Oroantral fistula viewed 21 days after the sinus lifting procedure.

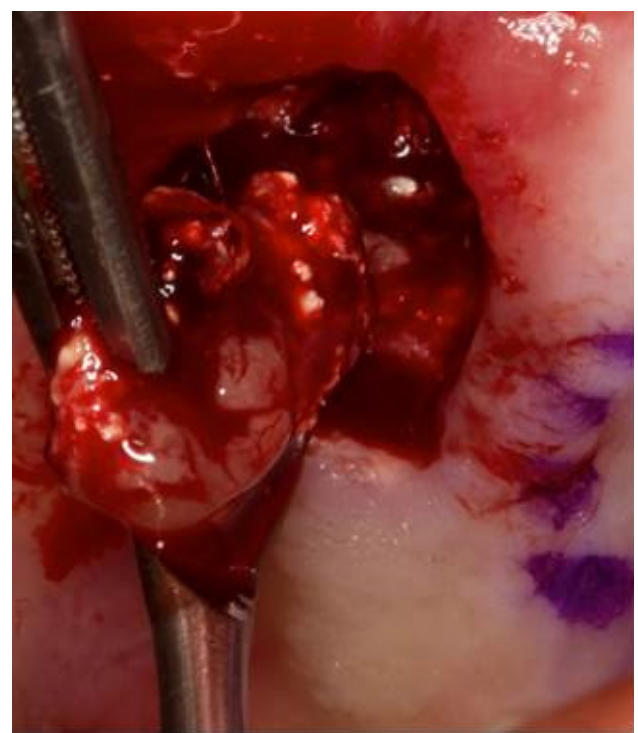

Figure 3. Curettage performed for removal of necrotic and inflammatory tissue.

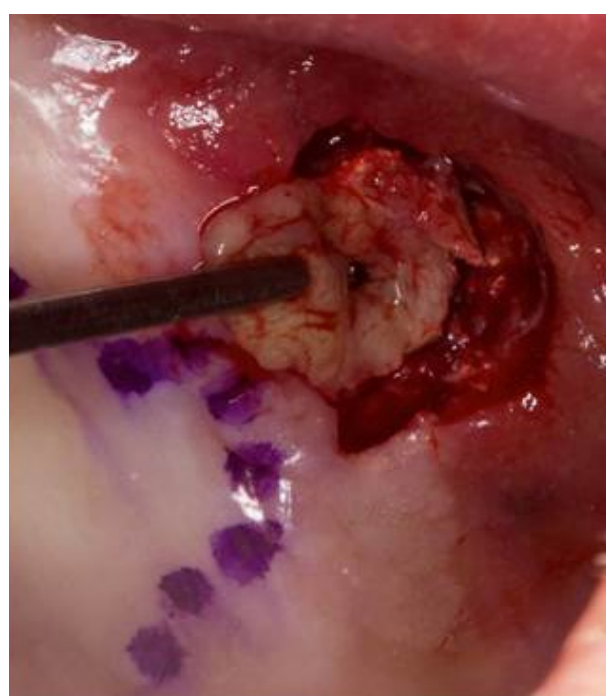

Figure 2. Complete dissection of the fistula walls.

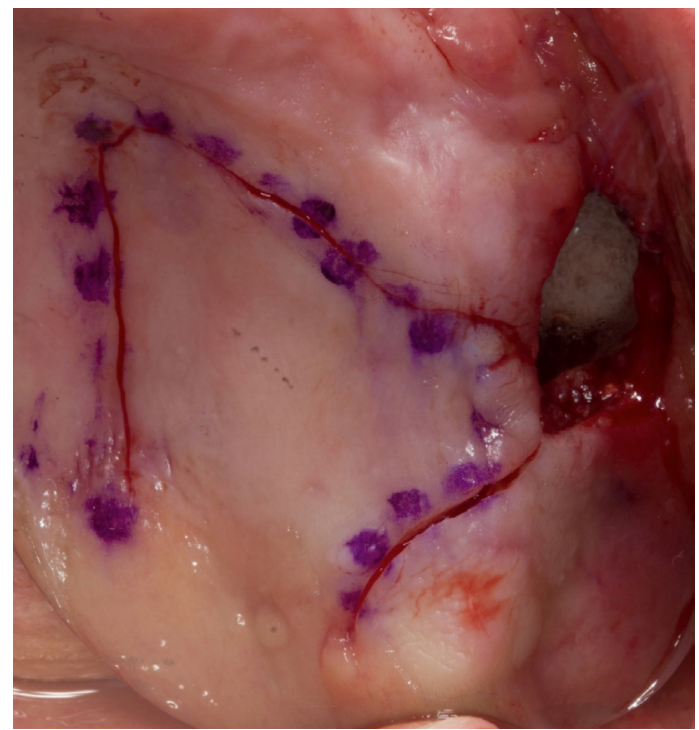

Figure 4. Marking of the incision. 


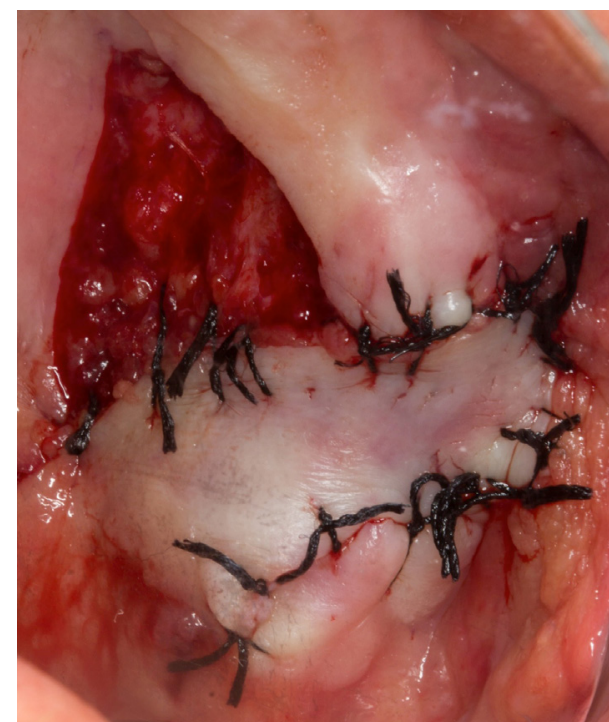

Figure 5. Fistula completely sutured.

\section{DISCUSSION}

Despite being well documented in the literature and strongly supported by the positive results of many case series, the sinus lifting procedure for bone grafting onto the maxillary sinus floor may leave serious sequelae if basic principles of surgical technique are not followed ${ }^{22}$. In the absence of meticulous fixation, rupture of the sinus membrane during surgery may lead to graft contamination due to its contact with the maxillary sinus chamber, which will frequently lead to oroantral communication and drainage of purulent secretion into the oral cavity. In the case reported herein, the dimension of the communication led us to suspect that, in addition to contamination of the graft through the sinus membrane, a dehiscence of the sutures may also have occurred, probably due to the lack of bone support at the border of the incision lines.

Some cases of moderate graft infection may regress with antibiotic therapy, but only when administered in the early stages of the process, with precisely selected agents at massive doses ${ }^{22-23}$. Severe cases of infection, however, should be approached more assertively and as early as possible, as trying to maintain the graft in place may cause extensive bone loss, especially on the buccal wall of the sinus, which would highly increase the level of complexity for surgical repair of the oroantral communication due to its inconvenient contour and dimension. Based on this principle, as soon as the severity of the infectious status was assessed, antibiotic therapy was initiated (500 mg amoxicillin combined with $400 \mathrm{mg}$

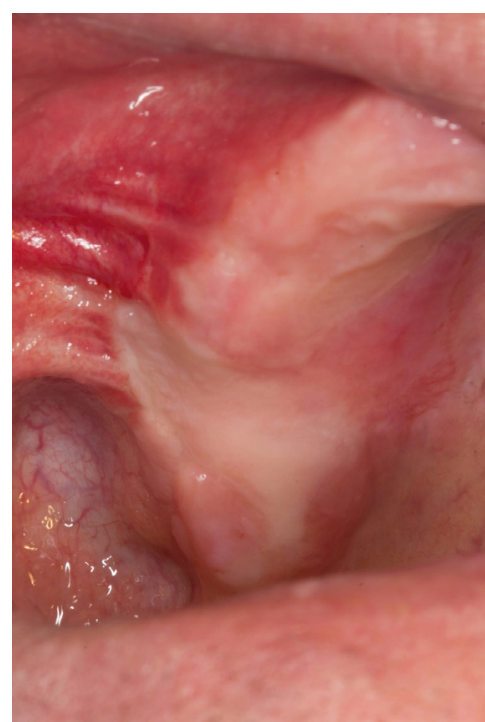

Figure 6. Close-up view of healing 30 days after surgery.

metronidazole every 8 hours) and surgery for closure of the oroantral communication was scheduled. It is worth noting that, although complete control of the infectious process is recommended before the attempt for closing the oroantral communication is carried out, in this case, due to the large amount of necrotic and inflammatory tissues found during the surgery, it was evident that the infection would not regress with systemic therapy alone. Thus, in this case, antibiotic therapy was efficient to minimize the infectious status and increase the chance of success of the surgical procedure.

The major disadvantage of the Rehrmann buccal flap for correcting oroantral communications seems to be the loss of buccal sulcus depth. A variation of this technique, the Môczáir flap, in which the buccal pedicle is laterally displaced, minimizes such loss, though its indication is limited to patients who are edentulous in in the area around the communication ${ }^{10}$. On the other hand, great enthusiasm can be found in the current literature regarding use of the buccal fat pad for closure of oroantral communications. This technique reportedly allows buccal sulcus preservation and uses a tissue that is highly vascularized, prone to re-epithelization, and that can be harvested right next to the receptor site. Despite these advantages, however, some authors still prefer to reserve this technique for fistulae that are larger or relatively more posteriorly located, or for cases in which closure with the buccal flap has already been attempted ${ }^{21,24}$.

Although it is not the most commonly used technique for closure of oroantral communications, the 
palate-derived flap features several advantages which make it the first choice for several authors in the literature ${ }^{17-20}$. It is a flap that is richly supplied by the greater palatine artery and by the numerous anastomoses throughout the palate; it can present satisfactory thickness, width and texture; and, despite a lack of consensus, its harvesting generally does not pose technical difficulty ${ }^{20}$. According to some authors, palatal flaps should be used preferably for oroantral communications larger than $10 \mathrm{~mm}^{25}$. In the present clinical report, the authors chose to use a palatederived flap to close a fistula that was located around the pre-molar region, albeit towards the buccal side of the ridge. In addition to our previous experience and affinity for this particular technique, our choice was also related to the advantageous factors described above, i.e., reliable nutrition combined with generous thickness and texture, which can be assured even when the incision divides the mucosal and periosteal portions of the flap, as in this case. Another advantage that seems not to draw much attention in the literature is the abundance of keratinized mucosa that can be achieved in the area of the fistula with a palatal flap, which can be a valuable asset to provide support for a future dental implant in the region ${ }^{26-27}$.

As far as the reported limitations of the palatal flap are concerned, limited elasticity did not jeopardize its satisfactory displacement, as, with the technique used, the flap was detached from the periosteum and extended all the way towards the posterior third and soft portion of the palate, where limited elasticity is no longer critical ${ }^{16}$. Splitting of the flap should be carried out very judiciously, because, as previously demonstrated for random flaps, survival of the palatal pedicle flap is dependent on the ratio between the length and the thickness of the flap ${ }^{19}$, among other factors. Discomfort in the donor site, reported by some authors for palatal flaps, was minimized through the use of a resin protecting plate over the surgical cement, which was kept in place for 10 days after surgery. This procedure followed the recommendation of authors who claim that the use of such devices could significantly reduce mechanical irritation and postoperative discomfort in patients who have undergone palatal connective

\section{REFERENCES}

1. Boyne PJ, James RA. Grafting of the maxillary sinus floor with autogenous marrow and bone. J Oral Surg. 1980;38(8):613-6.

2. Tatum Junior H. Maxillary and sinus implant reconstructions. Dent Clin North Am. 1986;30(2):207-29. tissue removal procedures ${ }^{28}$. It is also worth noting that maintenance of the connective tissue over the palatal donor site, due to the splitting of the flap, certainly contributed to postoperative comfort in this area. Within the first few weeks after surgery, we observed the health and abundant blood supply of the flap, imminent healing at the donor site, maintenance of buccal sulcus depth and resolution of all signs and symptoms of infection. Thirty days after surgery, the mucosa was completely healed and epithelized at both the donor and receptor sites. A Valsalva maneuver was negative and the patient was satisfied and free from all signs and symptoms of oroantral fistula.

\section{CONCLUSION}

The clinical case here reported supports the efficacy of the palatal pedicle flap as an adequate technique for closure of a large-diameter oroantral fistula created due to failure of a sinus lifting procedure for bone grafting onto the maxillary sinus floor. The palatal pedicle flap, combined with antibiotic therapy and curettage of the infected graft, can be an excellent alternative for closure of large oroantral fistulae near the crest of the maxillary ridge.

\section{Acknowledgment}

The authors thank Mr. Daniel Augusto Duarte Soares for the photographs.

\section{Collaborators}

C MARCANTONIO participated in the surgery and writing of the paper. M PALMIERI participated in the surgery, literature review and writing of the paper. DV GORGA participated in editing of the images and writing of the paper. MO PEREIRA participated in literature review and writing of the paper. LG NíCOLI participated in surgery, postoperative control and writing of the paper. WA JORGE coordinated the team and participated in the literature review and writing of the paper.

3. Summers RB. A new concept in maxillary implant surgery: the osteotome technique. Compendium. 1994;15(2):152-18.

4. Goene R, Bianchesi C, Huerzeler M, Del Lupo R, Testori $T$, Davarpanah $M$, et al. Performance of short implants in partial restorations: 3-year follow-up of Osseotite implants. Implant Dent. 2005;14(3):274-80. doi: 10.1097/01. id.0000173335.90854.d8 
5. Stern A, Green J. Sinus lift procedures: an overview of current techniques. Dent Clin North Am. 2012;56(1):219-33. doi: 10.1016/j.cden.2011.09.003

6. Tuna T, Yorgidis M, Strub JR. Prognosis of implants and fixed restorations after lateral sinus elevation: a literature review. J Oral Rehabil. 2012;39(3):226-38. doi: 10.1111/j.13652842.2011.02259.x

7. Del Fabbro M, Rosano G, Taschieri S. Implant survival rates after maxillary sinus augmentation. Eur J Oral Sci. 2008;116(6):497506. doi: 10.1111/j.1600-0722.2008.00571.x

8. Barone A, Santini S, Sbordone L, Crespi R, Covani U. A clinical study of the outcomes and complications associated with maxillary sinus augmentation. Int J Oral Maxillofac Implants. 2006;21(1):81-5

9. Anavi $Y$, Allon DM, Avishai G, Calderon S. Complications of maxillary sinus augmentations in a selective series of patients. Oral Surg Oral Med Oral Pathol Oral Radiol Endod. 2008;106(1):34-8. doi: 10.1016/j.tripleo.2007.09.021

10. Visscher SH, van Minnen B, Bos RR. Closure of oroantral communications: a review of the literature. J Oral Maxillofac Surg. 2010;68(6):1384-91. doi: 10.1016/j.joms.2009.07.044

11. Egyedi P. Utilization of the buccal fat pad for closure of oroantral and/or oro-nasal communications. J Maxillofac Surg. 1977:5(4):241-4. doi:10.1016/\$0301-0503(77)80117-3

12. Poeschl PW, Baumann A, Russmueller G, Poeschl E, Klug C Ewers R. Closure of oroantral communications with Bichat's buccal fat pad. J Oral Maxillofac Surg. 2009;67(7):1460-6. doi: 10.1016/j.joms.2009.03.049

13. Hanazawa $Y$, Itoh K, Mabashi T, Sato K. Closure of oroantral communications using a pedicled buccal fat pad graft. J Oral Maxillofac Surg. 1995;53(7):771-6. doi:10.1016/02782391(95)90329-1

14. Jain MK, Ramesh C, Sankar K, Lokesh Babu KT. Pedicled buccal fat pad in the management of oroantral fistula: a clinical study of 15 cases. Int J Oral Maxillofac Surg. 2012;41(8):1025-9. doi: 10.1016/j.jom.2012.02.014

15. Candamourty R, Jain MK, Sankar K, Babu MR. Double-layered closure of oroantral fistula using buccal fat pad and buccal advancement flap. J Nat Sci Biol Med. 2012;3(2):203-5. doi: 10.4103/0976-9668.101930

16. Salins PC, Kishore SK. Anteriorly based palatal flap for closure of large oroantral fistula. Oral Surg Oral Med Oral Pathol Oral Radiol Endod. 1996;82(3):253-6. doi:10.1016/S1079-2104(96)803489

17. Yalcin S, Oncu B, Emes Y, Atalay B, Aktas I. Surgical treatment of oroantral fistulas: a clinical study of 23 cases. J Oral Maxillofac Surg. 2011;69(2):333-9. doi: 10.1016/j.joms.2010.02.061
18. Yamazaki $Y$, Yamaoka $M$, Hirayama $M$, Shimada $H$. The submucosal island flap in the closure of oro-antral fistula. Br J Oral Maxillofac Surg. 1985;23(4):259-63. doi:10.1016/02664356(85)90041-5

19. Lee JJ, Kok SH, Chang HH, Yang PJ, Hahn LJ, Kuo YS. Repair of oroantral communications in the third molar region by random palatal flap. Int J Oral Maxillofac Surg. 2002;31(6):677-80. doi:10.1054/ijom.2001.0209

20. Anavi Y, Gal G, Silfen R, Calderon S. Palatal rotationadvancement flap for delayed repair of oroantral fistula: a retrospective evaluation of 63 cases. Oral Surg Oral Med Oral Pathol Oral Radiol Endod. 2003:96(5):527-34. doi:10.1016/ S1079-2104(03)00470-0

21. Borgonovo $A E$, Berardinelli FV, Favale $M$, Maiorana C. Surgical options in oroantral fistula treatment. Open Dent J. 2012;6:948. doi: $10.2174 / 1874210601206010094$

22. Testori T, Drago L, Wallace SS, Capelli M, Galli F, Zuffetti F, et al. Prevention and treatment of postoperative infections after sinus elevation surgery: clinical consensus and recommendations. Int J Dent. 2012:2012:365809. doi: 10.1155/2012/365809

23. Dym $\mathrm{H}$, Wolf JC. Oroantral communication. Oral Maxillofac Surg Clin North Am. 2012;24(2):239-47. doi: 10.1016/j. coms.2012.01.015

24. Abad-Gallegos M, Figueiredo R, Rodriguez-Baeza A, Gay-Escoda C. Use of Bichat's buccal fat pad for the sealing of orosinusal communications. A presentation of 8 cases. Med Oral Patol Oral Cir Bucal. 2011;16(2):e215-219. doi:10.4317/medoral.16.e215

25. Er N, Tuncer HY, Karaca C, Copuroglu S. Treatment of oroantral fistulas using bony press-fit technique. J Oral Maxillofac Surg. 2013;71(4):659-66. doi: 10.1016/j.joms.2012.12.010

26. Lin $\mathrm{GH}$, Chan $\mathrm{HL}$, Wang $\mathrm{HL}$. The significance of keratinized mucosa on implant health: a systematic review. J Periodontol. 2013;84(12):1755-67. doi: 10.1902/jop.2013.120688

27. Brito C, Tenenbaum HC, Wong BK, Schmitt C, Nogueira-Filho G. Is keratinized mucosa indispensable to maintain peri-implant health? A systematic review of the literature. J Biomed Mater Res B Appl Biomater. 2014;102(3):643-50. doi: 10.1002/ jbm.b.33042

28. Zuhr O, Baumer D, Hurzeler M. The addition of soft tissue replacement grafts in plastic periodontal and implant surgery: critical elements in design and execution. J Clin Periodontol. 2014;41(Suppl 15):S123-142. doi: 10.1111/jcpe.12185

Received on: 13/3/2015

Final version resubmitted on: 20/5/2015 Approved on: 11/8/2015 